https://doi.org/10.15407/scine17.04.044

SEMYKIN, S. I. (https://orcid.org/0000-0002-7365-2259),

GOLUB, T. S. (https://orcid.org/0000-0001-9269-2953)

and DUDCHENKO, S. A. (https://orcid.org/0000-0002-7319-9896)

Iron and Steel Institute of Z.I. Nekrasov, the NAS of Ukraine,

1, Akad. Starodubov Sq., Dnipro, 49107, Ukraine,

+380 56790 0512, office.isi@nas.gov.ua

\title{
DIRECT OBSERVATION \\ OF HIGH-TEMPERATURE AREAS \\ OF METAL MELT AT OXYGEN \\ CONVERTER BLOWING WITH LOW VOLTAGE APPLICATION
}

Introduction. The process of oxygen conversion, despite the existing improvements, can be supplemented by physical methods of influence, including the unconventional method of applying low-voltage potential developed at the Iron and Steel Institute of the NAS of Ukraine.

Problem Statement. The studies of the method of low-voltage potential application on 60, 160 and 250 ton converters have shown that the technology intensifies thermophysical and hydrodynamic processes in the gasslag-metal system and increases the converter process efficiency.

Purpose. The purpose of this research is to study the features of the influence on the reaction zones of the low voltage potential application at four blowing options with the use of high-temperature physical model.

Materials and Methods. A physical model that simulates the top, bottom and combined oxygen blowing under low-voltage potential application of different polarity on the lance has been used. An insert of a transparent quartz plate is made in one of the walls for visual observation and video recording. The top blowing is conducted with two nozzle lance (nozzle diameter $1.7 \mathrm{~mm}$ with an angle of $30^{\circ}$ to the lance). The bottom blowing is conducted with a bottom tuyere with a $1.5 \mathrm{~mm}$ diameter central nozzle. Combined blowing is realized by a combination of these options.

Results. The visual observation of the reaction zones with different blowing options has shown that the highest temperature and the largest dimensions of the brightest parts of the bath correspond to the combined blowing, while the lowest ones are reported for the bottom blowing. While applying the low-voltage potential method it has been established that the reaction zone is longer at the positive polarity on the lance, during the period of silicon oxidation, and at the negative polarity on the lance, during the period of intense carbon oxidation.

The video of gas bubbles flotation, probably $\mathrm{CO}$, has shown that the bubbles are formed more intensively in the case of negative polarity on the lance.

Conclusions. The applied technique has allowed estimating the influence of low-voltage potential application on the geometric parameters of the reaction zone.

Keywords: basic oxygen converter processes, high temperature simulation, reaction zone, and low voltage potential application to the lance-metal bath blowing.

Citation: Semykin, S. I., Golub, T. S., and Dudchenko, S. A. Direct Observation of High-Temperature Areas of Metal Melt at Oxygen Converter Blowing with Low Voltage Application. Sci. innov. 2021. V. 17, no. 4. P. 44-54. https://doi.org/10.15407/scine17.04.044 
Oxygen-converter is a unit for steelmaking by oxygen blowing of liquid iron, which ensures the oxidation of iron impurities (silicon, manganese, carbon, etc.) and their subsequent removal from the melt. Currently, it is the main way of steel production in the world metallurgical practice [1-2].

There are several ways of oxygen blowing in the converter: top blowing, bottom blowing and a combination of these two methods with blowing through the bottom by oxygen covered with a natural gas or neutral gas [1-2]. Despite a long period of oxygen converter process research and development, today there are several issues that can be solved by physical methods. These methods include the unconventional method of low voltage potential application, which is developed at the Iron and Steel Institute of the NAS of Ukraine (ISI NASU). The laboratory and industrial practice of its development on 60-ton, 160-ton, and 250-ton converters has shown that the technology intensifies the thermo-physical and hydrodynamic processes in the gas-slag-metal system and increases the thermal and material efficiency of the process [3].

The purpose of this research is to study, based on the high-temperature physical model, the features of the influence on the reaction zones of the low voltage potential application to the lancemetal bath circuit at four blowing options.

The oxygen converter is a complex, multi-process, and quite composite unit. It is necessary to understand the processes that occur in it for the purpose of controlling them. Scientific views on the nature of gas jet/steel-smelting bath interaction, the structure and parameters of the reaction zones were formulated in 1959 by V. I. Baptizmanskiy, V. I. Yavoyskiy, M. Ya. Medzhibozhskiy and others [4-6], and subsequently extended by A. G. Cherniatevych, E. Ya. Zarvin, V. B. Ohotskiy, E.V. Protopopov, and others [7-9]. At present, the most modern research method of gas/liquid melts interaction, including the presence of a slag phase, is the method of high-temperature simulation guided by A.G. Cherniatevych [7-8].

Laboratory research has been conducted at ISI NASU, with the use of $40 \mathrm{~kg}$ physical model, simulating top, bottom, and combined blowing in oxygen converter under low voltage potential application. For visual observation and video registration, an insert of $10 \mathrm{~mm}$ thick transparent quartz plate in one of the walls is made. The schematic diagram of the experimental plant is shown in Fig. 1.

At first, a $40 \mathrm{~kg}$ pig iron is melted in an induction furnace and heated to a temperature of about
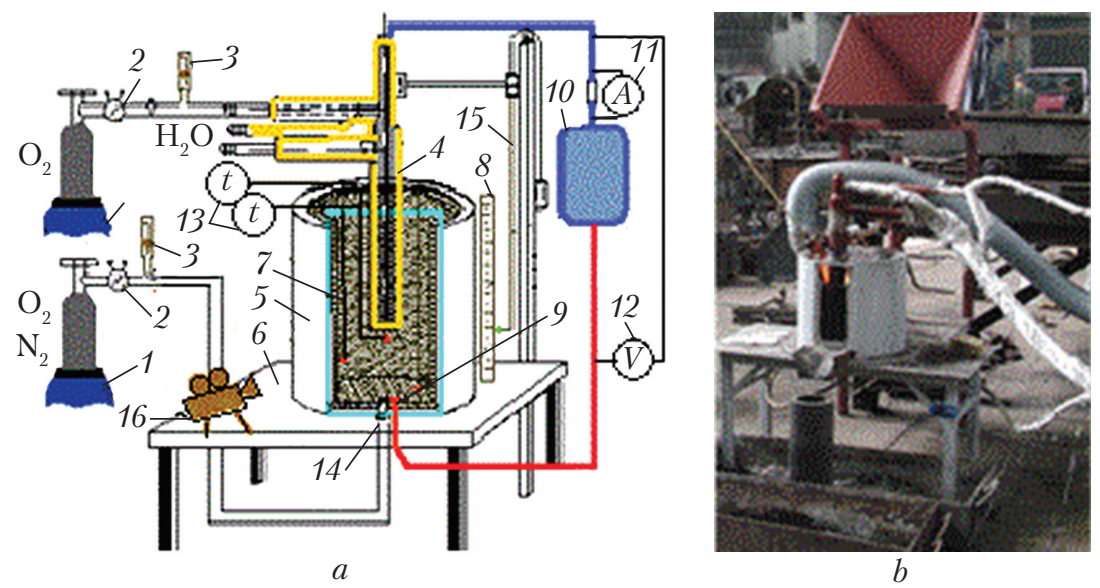

Fig. 1. Diagram $(a)$ and photo $(b)$ of the model for visual observation of iron-carbon melt blowing with oxygen with low voltage potential application: 1 - gas balloons; 2 - pressure reducers; 3 - flow meters; 4 - top blowing lance; 5 - model reactor; 6 - table; 7 - quartz glass wall $(140 \mathrm{~mm} \times 360 \mathrm{~mm}) ; 8$ - lance position indicator; 9 - bottom electrode; 10 - low voltage source of power; 11 - ammeter; 12 - voltmeter; 13 - thermocouples; 14 - bottom blowing tuyere; 15 - lance moving device, 16 - video camera 
$1400{ }^{\circ} \mathrm{C}$. Then the melt is poured into the model (the height is $140 \mathrm{~mm}$ ); the lance is placed to the working height in such a way as the axis of the jet from one of the nozzles is directed towards the quartz wall. It helps to display the contours and the internal structure of the interaction zone between the oxygen jet and the metal bath, which is called the reaction zone, on the surface of the transparent wall for its video recording as the brightest area of the bath. Then the model reactor is covered by a lid equipped with a metal hose for removing the exhaust gases. The blowing time is determined by the lifetime of the quartz wall and is about 3 minutes.

During the blowing with $99.6 \%$ purity oxygen, the electric current of positive or negative polarity from the current source is applied to the isolated lance and that of the opposite polarity is applied to the bottom electrode, to make an electric circuit. The voltage on the lance and the metal bath is $5-8 \mathrm{~V}$. In the bottom blowing option, a low voltage is applied to the top immersed electrode and to the bottom electrode.

\section{The blowing parameters are as follows:}

The top blowing (option A) is provided through a two-nozzle oxygen lance placed at a height of 3033 nozzle calibers (the nozzle diameter is $1.7 \mathrm{~mm}$, the angle of inclination of the nozzle to the lance axis is 30 degrees). The gas pressure is $0.2-0.3 \mathrm{MPa}$ at a flow rate of $0.098-0.147 \mathrm{~m}^{3} / \mathrm{min}$.

The bottom oxygen blowing (option $\mathbf{B}$ ) is carried out through the bottom double circuit tuyere with a diameter of the central nozzle of $1.5 \mathrm{~mm}$ and a slot of $0.4 \mathrm{~mm}$ around the nozzle. The oxygen at a pressure of $0.05-0.1 \mathrm{MPa}$ and a flow rate of $0.0096-0.0191 \mathrm{~m}^{3} / \mathrm{min}$ is supplied with a covering flux of natural gas at a pressure of $0.005 \mathrm{MPa}$ and a flow rate of $0.001 \mathrm{~m}^{3} / \mathrm{min}$.

The combined blowing (options $\mathbf{C}$ and $\mathbf{D}$ ) is realized by applying the aforementioned top and bottom blowing with the replacement of oxygen by nitrogen in option $\mathrm{D}$.

Technological and electrical parameters as well as the blowing process are recorded by high-speed camcorder CASIO EXILIM EX F1 (300 frames per second). The integral brightness of the reaction zone is recorded by a pyrometer Benetech GM2200 with a measuring range of $200-2200{ }^{\circ} \mathrm{C}( \pm 1 \%)$. The temperature of the bath during the blowing is fixed by the platinum thermocouple with a measuring range of $200-1750{ }^{\circ} \mathrm{C}( \pm 1 \%)$.

First of all, it has been noted that the metal bath temperature in the upper and bottom areas changes (the average data on the blowing periods are shown in Table 1). The features of change in the temperature are determined primarily by the location of high-temperature reaction zone. The analysis of the heating in the upper area (called the primary reaction zone [7-9]) of the bath has revealed that the highest temperature of the primary reaction zone corresponds to the combined oxygen/oxygen blowing (option C), particularly, at the beginning of the carbon oxidation period (after $2.5 \mathrm{~min}$ ). It is explained by the presence of two reaction zones of interaction of oxygen jet with metal, which are sources of high temperature. Option A has a little bit lower temperature level in the sub-lance area than option $\mathrm{D}$, because of better heat and mass transfer in D option, as a result of additional bottom neutral gas stirring. As expected, the upper area of the metal bath has the lowest temperature in the conditions of the bottom blowing (option B) among all options.

The metal temperature in the bottom area decreases in the course of blowing for option A and increases in the options with bottom blowing, especially in the case of the combined oxygen/oxygen blowing (option $\mathrm{C}$ ).

The influence of low-voltage potential manifests itself as follows. In the case of the top oxygen blowing (options $\mathrm{A}, \mathrm{C}$, and D) the application of low voltage potential causes an increase in the temperature both in the upper and in the bottom areas, especially at positive polarity on the lance. For heating with low voltage application of positive polarity, the temperature in the upper area is higher by $45-150^{\circ} \mathrm{C}$, in the case of option $\mathrm{A}$, and by $130-200^{\circ} \mathrm{C}$, in the case of options $\mathrm{C}$ and $\mathrm{D}$, as compared with heating without impact, versus an increase in the temperature at negative pola- 
rity of potential by $25-100{ }^{\circ} \mathrm{C}$, in the case of option $\mathrm{A}$, and by $80-130{ }^{\circ} \mathrm{C}$, in the case of options $\mathrm{C}$ and $\mathrm{D}$, respectively.

The comparative analysis of the bottom electrode area temperature that characterizes the heating of the lower bottom layers of the bath during the blowing (see Table 1) has revealed that the highest temperature in this area corresponds to the combined oxygen/oxygen blowing (option C). It can be explained both by the additional reaction zone and by more dynamic course of the mixing process.

For option B, in the bottom area, the temperature is slightly lower, which is probably explained by the effect of heat consumption by the decomposition of hydrocarbons of natural gas.

The decrease in the bottom temperature for option A (the top blowing) during the blowing means the worst bath mixing conditions, as a result of the fact that the Archimedes forces, arising in the upper layers of the bath, are directed upwards, and do not contribute to the effective mixing of the entire bath. This deficiency has not been noted for option D (the combined blowing with neutral gas) that is similar to option $\mathrm{C}$ with a slightly lower temperature. Probably, the reason is the cooling of the bath with neutral gas, which, however, is quickly compensated by heat from the top blowing because of an active bath stirring.

The low voltage application provides a higher bottom temperature than in the case of comparative melts: at negative polarity on the top electrode, by $20-25{ }^{\circ} \mathrm{C}$ for option $\mathrm{A}$ and by $26-50{ }^{\circ} \mathrm{C}$, for options $\mathrm{C}$ and $\mathrm{D}$; and at positive polarity of potential on the electrode, by $15-25{ }^{\circ} \mathrm{C}$, for option $\mathrm{A}$ and by $10-50{ }^{\circ} \mathrm{C}$, for $\mathrm{C}$ and $\mathrm{D}$ options.

The video analysis of reaction zones that are the conjugate volumes of interaction of the oxygen jet with the metal bath has revealed that they are visually distinguishable as the brightest central region along the jet axis and the surrounding area with a slightly lower temperature. It has been found that the shape and dimensions of the reaction zone primarily determined by blowing type (top, combined, bottom) and blowing periods correspond to the priority of oxidation of silicon or carbon and are influenced by the polarity of low voltage application to the lance.

Table 1. Temperature of the Upper Reaction Zone and Metal near the Bottom Electrode for Different Blowing Options

\begin{tabular}{|c|c|c|c|c|c|c|c|}
\hline \multirow{3}{*}{\multicolumn{2}{|c|}{$\begin{array}{l}\text { Blowing type } \\
\text { and period } \\
\text { of oxidation }\end{array}$}} & \multicolumn{6}{|c|}{ Temperature for the experimental options, ${ }^{\circ} \mathrm{C}( \pm 1 \%)$} \\
\hline & & \multicolumn{2}{|c|}{ without low voltage application } & \multicolumn{2}{|c|}{$\begin{array}{l}\text { low voltage application } \\
\text { of negative polarity to the lance }\end{array}$} & \multicolumn{2}{|c|}{$\begin{array}{c}\text { low voltage application } \\
\text { of positive polarity to the lance }\end{array}$} \\
\hline & & Upper zone* & Bottom zone** & Upper zone & Bottom zone & Upper zone & Bottom zone \\
\hline \multirow[t]{3}{*}{1} & Top oxygen blowing & & & & & & \\
\hline & Silicon oxidation & 1545 & 1400 & 1570 & 1420 & 1590 & 1415 \\
\hline & Carbon oxidation & 1710 & 1380 & 1810 & 1405 & 1860 & 1405 \\
\hline \multirow[t]{3}{*}{2} & Bottom oxygen blowing & & & & & & \\
\hline & Silicon oxidation & 1400 & 1500 & 1400 & 1520 & 1400 & 1516 \\
\hline & Carbon oxidation & 1375 & 1530 & 1383 & 1580 & 1386 & 1580 \\
\hline \multirow[t]{3}{*}{3} & Combined oxygen/oxyge & blowing & & & & & \\
\hline & Silicon oxidation & 1510 & 1500 & 1600 & 1530 & 1650 & 1535 \\
\hline & Carbon oxidation & 1800 & 1550 & 1930 & 1600 & 2000 & 1604 \\
\hline \multirow[t]{3}{*}{4} & Combined oxygen/nitrog & n blowing & & & & & \\
\hline & Silicon oxidation & 1500 & 1430 & 1580 & 1440 & 1630 & 1440 \\
\hline & Carbon oxidation & 1780 & 1482 & 1880 & 1508 & 1920 & 1514 \\
\hline
\end{tabular}

* _ obtained by a pyrometer, ** _ obtained by the platinum thermocouple 
As an example, the view of the reaction zones recorded through a quartz wall, for the four blowing options, are shown on Fig. 2. The photo shows that the luminous sub-lance area separates into zones. The central bright area of oxygen gas/melt interaction (the primary reaction zone) [7-9], which is surrounded by less bright intermediate area (the secondary reaction zone) runs deeper into the volume of the metal bath. In option A, there is a dark band that probably is caused by accumulation of quartz glass oxidation products. The bottom blowing is characterized by the formation of a luminous gas in the bottom part (the primary reaction zone) and by less bright secondary reaction zone that is larger in size as compared with the primary reaction zone. In options $\mathrm{A}$ and $\mathrm{B}$, the most significant difference in brightness between the reaction zone and the total bulk of the metal has been reported.

The combined blowing pattern is different from that resulting from simple superposition of the top and the bottom blowing. In the top part of the model, there is a bright area located higher than in the case of the top blowing, and in the bottom part, the dimensions of the second primary reaction zone is much wider than in the case of bottom blowing. It should be noted that the dark band in this case does not surround each zone separately, but both together. It is supposedly explained by the gas-dynamic interaction of gas jets from the top and the bottom lances.

To identify the peculiarities of the influence of the low-voltage application on the geometric parameters of the reaction zones, the experiments without electrical impact have been carried out and analyzed (Fig. 3). First of all, it has been found that irrespective of the blowing option, the reaction zones, with constant blowing parameters, periodically change their dimensions by about 20 $50 \%$ because of the pulsating nature of the jet interaction with the bath. It has been established that the dimensions of the primary reaction zone vary depending on the method of gas supply with a frequency of about $6-7 \mathrm{~Hz}$ for the top oxygen blowing and 10-11 Hz for the bottom oxygen blo- wing. In addition, it has been noted that the jet pulsation frequency decreases if the priority in the oxidation of silicon changes to carbon oxidation by $10-12 \%$, thereby confirming the gas-dynamic nature of the interaction of gas jet with liquid melt. The analysis of the pulsation frequencies of the reaction zones in the case of low voltage application has not shown any noticeable effect of the polarity of potential. At the same time, a significant influence of the low voltage potential polarity on the geometric parameters of the primary reaction zone has been noted.

The comparative analysis of low voltage potential impact on the reaction zones for different blowing methods has been made based on measured main parameters of the primary reaction zone during the periods of its visual maximum dimensions: the penetration length along the jet axis $(h)$ and the diameter $(D)$. Both parameters have been analyzed for the four blowing options, with and without the low voltage application of both the negative and positive polarity to the lance. The average results are shown in Table 2 . The analysis is made given the features of two main periods of blowing: the oxidation of silicon and the oxidation of carbon.

In Table 2, the measurement results are grouped into vertical columns according to the experimental options of potential supply. In the analysis of the material presented in the mentioned Table, the criterion of geometric shape $(c)$, which characterizes the ratio of the zone depth to its diameter, is used. As expected [7-9], the method of oxygen blowing determines the geometric ratio of the penetration depth and the diameter of the interaction zones. It has been reported, that for the melts without the low voltage application in the case of top blowing, coefficient $c$ is approximately equal to 1 during the whole blowing period. It means that the depth of jet penetration with the formation of the primary reaction zone and its diameter are approximately equal to each other. In the case of bottom blowing, the unidirectional combination of Archimedes forces and inertial forces contributes to growing height of the 

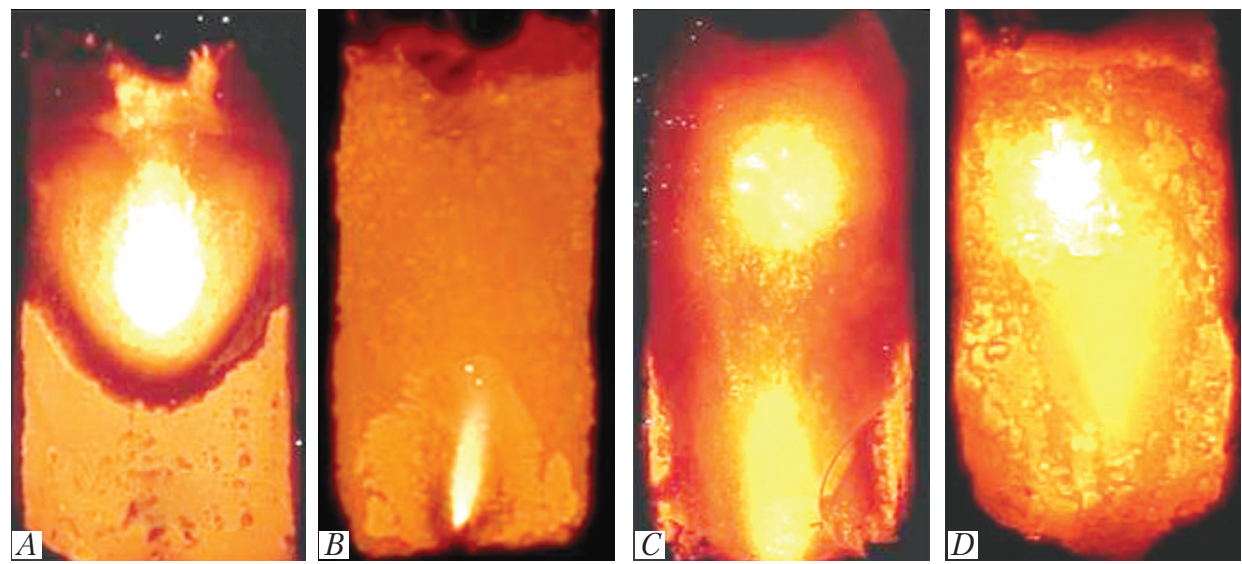

Fig. 2. Photo of reaction zones at top $(A)$, bottom $(B)$, combined $(C)$ and $(D)$ oxygen blowing with low voltage application of negative polarity

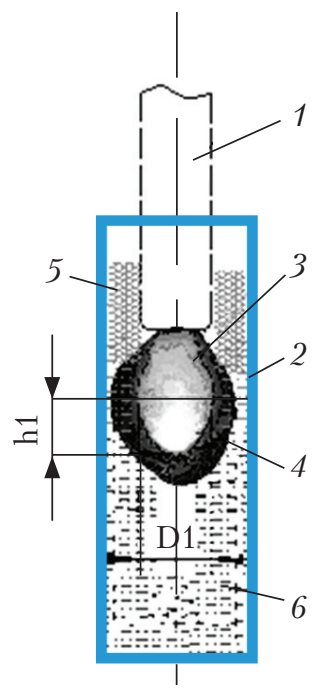

A

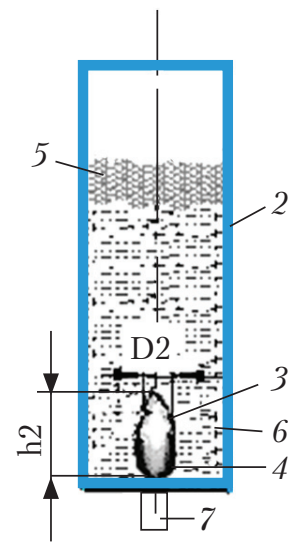

$B$

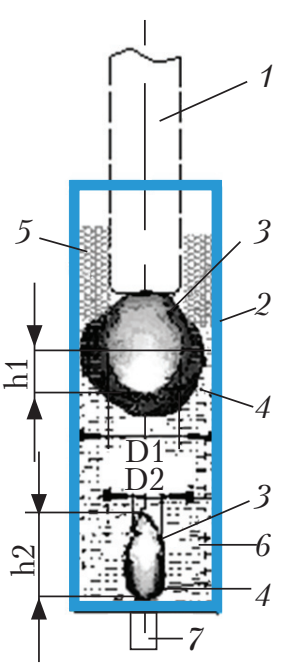

$C$

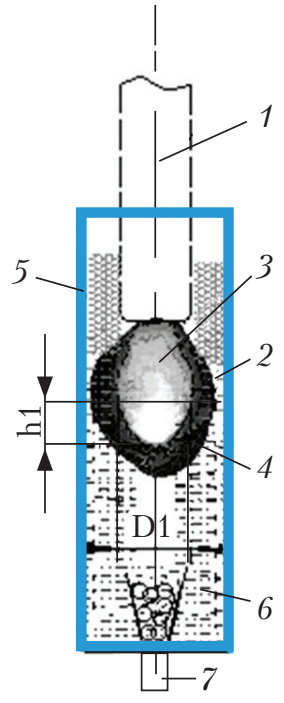

$D$

Fig. 3. The scheme of formation of the reaction zones at top $(A)$, bottom $(B)$, combined $(C)$ and $(D)$ oxygen blowing, $1-$ lance; 2 - quartz plate; 3 - primary reaction zone; 4 - zone of reaction products; 5 - slag-metal phase; 6 - metal melt; 7 bottom tuyere. h1, h2 - the depth of the primary reaction zone in upper and bottom parts of the model, respectively, D1 and D2 - the diameters of the primary reaction zones in upper and bottom parts of the model, respectively

primary reaction zone, and coefficient $c$ increases 2.7 times in the period of silicon oxidation and 2 times in the period of carbon oxidation.

At the same time, for the combined blowing, the supply of oxygen through the bottom significantly changes the shape of the primary reaction zone both in the upper and bottom parts: coefficient $c$ in the upper part decreases 2.3-2.1 times and 2.0-1.2 times in the bottom part, for the pe- riods of silicon and carbon oxidation, respectively. In the case of replacement of oxygen supplied from the bottom by nitrogen, coefficient $c$ for the upper part of the model increases, but is still 1.51.2 times lower than for the top blowing option, for the periods of silicon and carbon oxidation, respectively. It indicates a less pronounced effect of nitrogen flows as compared with oxygen flows because of the absence of physicochemical reactions 


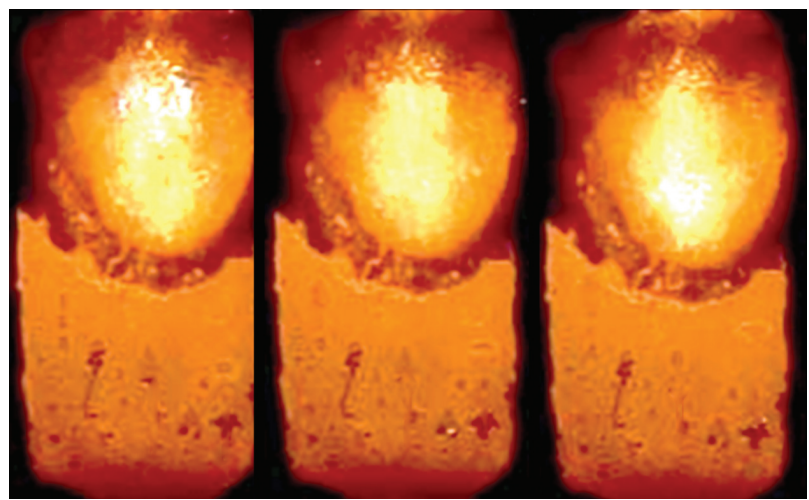

Fig. 4. Photos of gas bubbles generation and floating (arrows indicate the bubbles)

in the bottom part, which generate many reaction products in the form of floating gas-slag masses.

Considering the peculiarities of the influence of the low voltage application on the geometric parameters of the primary reaction zone, it should be noted that the electrical effects noticeably increase the volumes of the formed reaction zones in comparison with the melts without low voltage application. At the same time, it has been noted that the use of positive polarity of potential during the period of silicon oxidation significantly changes the length of the reaction zone, with coefficient $c$ increasing with respect to the comparative melts. During the period of carbon oxidation in this blowing option, the reaction zone diameter changes significantly, and coefficient $c$ decreases.

In the case of negative polarity of potential, the following effect on the opposite parameters of the reaction zone over the blowing period been established: during the period of silicon oxidation the diameter of the reaction zone increases, and coefficient $c$ decreases; during the period of carbon oxidation, the reaction zone becomes elongated, and coefficient $c$ increases, in comparison with the melts without low voltage application.

For the combined blowing options with low voltage application the same trend in the polarity influence on the primary reaction zones has been reported.

The formation of the primary and secondary reaction zones, both in the case of low voltage app- lication and the options without it, can be explained assuming that they are formed because of various physical and chemical processes that occur both sequentially and in parallel. So, very high temperature in the primary reaction zone (up to 2000$2500{ }^{\circ} \mathrm{C}$ ) leads to total oxidation of all elements of the metal bath. Since iron is the main component, it is oxidized first. Iron oxides are transferred to the secondary reaction zone that has a significantly lower temperature, and where the Gibbs energy law determines the priority of oxidation of the melt components. Based on the results of previous research [10], the change of the shape of primary reaction zones under the influence of the low voltage application may be explained as follows: as a result of high temperature in the reaction zone $\left(2500-3000{ }^{\circ} \mathrm{C}\right)$, there is a partial ionization of the oxygen flow with the formation of more negatively charged oxygen ions. This process can be described by the Sach equation [11]:

$$
\frac{m^{2}}{\left(1-m^{2}\right)}=\frac{2.4 \cdot 10^{-4} T^{2.5}}{P e^{-\mathrm{U} / k T}}
$$

where $m^{2} /\left(1-m^{2}\right)$ is the proportion of ionized gas; $T$ is temperature, $\mathrm{K} ; P$ is pressure, $\mathrm{Pa}$; $U$ is voltage, $\mathrm{V} ; k$ is the Boltzmann constant, $\mathrm{J} / \mathrm{K}$;

According to the equation, at a such temperature, the degree of oxygen ionization is $10-12 \%$. The external electric field has an additional effect that accelerates the charged oxygen particles. The result can be described by the equation:

$$
\operatorname{Vadd} .=K \cdot E,
$$

where $V$ add is additional (to the main flow) component of the charged ion velocity, $\mathrm{m} / \mathrm{s} ; K$ is the mobility coefficient numerically equal to the particle velocity, $\mathrm{cm} / \mathrm{s}$, at $\mathrm{E}=1 \mathrm{kV} / \mathrm{cm}$, for oxygen ions, it is $2.2 \mathrm{~cm} / \mathrm{s} / \mathrm{V} / \mathrm{cm} ; E$ is electric field strength, $\mathrm{V} / \mathrm{m}$. The electric field strength is determined by the following equation:

$$
E=U / h,
$$

where $U$ is voltage, $\mathrm{V} ; h$ is the distance between the electrodes, $\mathrm{m}$, it is taken 5 calibers of the nozzle for the conditions of the converter blowing, which corresponds to the initial section of the gas jet. The- 
refore, the additional velocity, given the proportion of the formed ions at a voltage of $30 \mathrm{~V}$, industrial lance nozzle diameter of $35 \mathrm{~mm}$, and 5 nozzles, is

Vadd. $=0.1 \cdot\left(2.2 \cdot 30 / 35 \cdot 10^{-3} \cdot 5\right)=3.8 \mathrm{~m} / \mathrm{s}$.

That is about $10 \%$ of the gas flow velocity.

The action of the electric field is determined by the combination of the direction of the oxygen flow, which is constant, and the direction of action of electric forces on the ions of the gas flow, which depends on the potential polarity on the lance. In the case of the negative polarity, because of coincidence of action of forces, the negatively charged oxygen ions speed up, and the oxygen stream receives additional acceleration. In the case of the positive polarity, on the contrary, a slowdown of oxygen flow is reported.

It has been established that favorable conditions for the electric current flow through the reaction zone in the case of the top blowing are formed at a distance of 10-15 nozzle calibers along the axis of the oxygen jet.

Table 2. Geometric Parameters of the Primary Reaction Zone for Different Blowing Options

\begin{tabular}{|c|c|c|c|c|c|c|c|}
\hline & \multirow{3}{*}{$\begin{array}{l}\text { Blowing type } \\
\text { and period } \\
\text { of oxidation }\end{array}$} & \multicolumn{6}{|c|}{$\begin{array}{l}\left.\text { The geometric parameters (height }(h) \text { and diameter }(D), \mathrm{m}^{*} 10^{-2}\right) \text { of the primary reaction zone } \\
\text { for the experiment options with deviation from the option without the low voltage application; } \\
\text { in brackets: the geometric shape criterion }(c=h / D)\end{array}$} \\
\hline & & \multicolumn{2}{|c|}{$\begin{array}{l}\text { without low voltage } \\
\text { application }\end{array}$} & \multicolumn{2}{|c|}{$\begin{array}{l}\text { low voltage application } \\
\text { of negative polarity to the lance }\end{array}$} & \multicolumn{2}{|c|}{$\begin{array}{c}\text { low voltage application } \\
\text { of positive polarity to the lance }\end{array}$} \\
\hline & & Upper zone & Bottom zone & Upper zone & Bottom zone & Upper zone & Bottom zone \\
\hline \multirow[t]{3}{*}{1} & \multicolumn{7}{|l|}{ Top oxygen blowing } \\
\hline & Silicon oxidation & $\begin{array}{l}4.2 \text { and } 4.0 \\
(1.05)\end{array}$ & & $\begin{array}{l}4.5 \text { and } 5.7 \\
\quad(0.79) \\
+7 \%+43 \%\end{array}$ & & $\begin{array}{l}6.0 \text { and } 4.8 \\
\quad(1.25) \\
+43 \%+20 \%\end{array}$ & \\
\hline & Carbon oxidation & $\begin{array}{l}4.2 \text { and } 4.2 \\
(1.0)\end{array}$ & & $\begin{array}{l}5.8 \text { and } 4.8 \\
\quad(1.21) \\
+38 \%+14 \%\end{array}$ & & $\begin{array}{l}4.6 \text { and } 5.4 \\
\quad(0.85) \\
+10 \%+29 \%\end{array}$ & \\
\hline \multirow[t]{3}{*}{2} & \multicolumn{7}{|c|}{ Bottom oxygen blowing } \\
\hline & Silicon oxidation & & $\begin{array}{l}4.2 \text { and } 1.5 \\
(2.8)\end{array}$ & & $\begin{array}{l}4.2 \text { and } 2.0 \\
\begin{array}{l}(2.10) \\
-+33 \%\end{array}\end{array}$ & & $\begin{array}{c}4.8 \text { and } 2.0 \\
(2.40) \\
+14 \%+33 \%\end{array}$ \\
\hline & Carbon oxidation & & $\begin{array}{l}3.0 \text { and } 1.5 \\
(2.0)\end{array}$ & & $\begin{array}{c}3.6 \text { and } 1.5 \\
\quad(2.40) \\
+20 \%-\end{array}$ & & $\begin{array}{c}3.6 \text { and } 1.5 \\
(2.40) \\
+20 \%-\end{array}$ \\
\hline \multirow[t]{3}{*}{3} & \multicolumn{7}{|c|}{ Combined oxygen/oxygen blowing } \\
\hline & Silicon oxidation & $\begin{array}{l}1.9 \text { and } 4.2 \\
(0.45)\end{array}$ & $\begin{array}{l}3.6 \text { and } 2.5 \\
(1.44)\end{array}$ & $\begin{array}{c}2.6 \text { and } 4.8 \\
(0.54) \\
+37 \%+14 \%\end{array}$ & $\begin{array}{c}3.8 \text { and } 2.5 \\
\quad(1.52) \\
+6 \%-\end{array}$ & $\begin{array}{c}3.0 \text { and } 5.2 \\
(0.58) \\
+58 \%+24 \%\end{array}$ & $\begin{array}{c}4.3 \text { and } 2.5 \\
\quad(1.72) \\
+19 \%-\end{array}$ \\
\hline & Carbon oxidation & $\begin{array}{l}1.8 \text { and } 3.8 \\
(0.47)\end{array}$ & $\begin{array}{l}3.2 \text { and } 1.9 \\
(1.68)\end{array}$ & $\begin{array}{l}2.8 \text { and } 3.9 \\
\quad(0.72) \\
+56 \%-\end{array}$ & $\begin{array}{c}6.0 \text { and } 2.4 \\
\quad(2.50) \\
+87 \%+26 \%\end{array}$ & $\begin{array}{c}2.4 \text { and } 4.3 \\
(0.56) \\
+33 \%+13 \%\end{array}$ & $\begin{array}{c}5.7 \text { and } 2.4 \\
(2.38) \\
+78 \%+26 \%\end{array}$ \\
\hline 4 & \multicolumn{7}{|c|}{ Combined oxygen/nitrogen blowing } \\
\hline & Silicon oxidation & $\begin{array}{l}3.3 \text { and } 4.8 \\
(0.69)\end{array}$ & & $\begin{array}{c}3.9 \text { and } 5.4 \\
\quad(0.72) \\
+18 \%+13 \%\end{array}$ & & $\begin{array}{c}4.3 \text { and } 5.4 \\
(0.79) \\
+30 \%+13 \%\end{array}$ & \\
\hline & Carbon oxidation & $\begin{array}{l}3.0 \text { and } 3.6 \\
(0.83)\end{array}$ & & $\begin{array}{c}3.9 \text { and } 4.7 \\
(0.83) \\
+30 \%+31 \%\end{array}$ & & $\begin{array}{c}3.0 \text { and } 4.8 \\
(0.63) \\
-+33 \%\end{array}$ & \\
\hline
\end{tabular}


Also the pattern of generation, growth, and floating of individual gas bubbles (probably, CO) along the quartz plate and the specific features of the low voltage potential influence on this process, which are the most evident in the case of the top blowing (option A) have been found (Fig. 4). The tendency towards an increase in the number of bubbles has been noted in the case of the low voltage application in comparison with a similar blowing period without the low voltage application. It has been revealed that the frequency of $\mathrm{CO}$ bubbles generation depends primarily on the depth of their formation: the deeper the place of formation, the more complicated their formation. And, consequently, they float less often because of the influence of the metal layer hydrostatic pressure on the formed bubble.

It has been found that the frequency of $\mathrm{CO}$ bubbles formation is higher in the case of the low voltage application of negative polarity during all blowing periods. It is probably because of the intensification of the decarburization process by this polarity. For example, bubbles formed at a depth of $5 \mathrm{~cm}$ at the negative polarity have a frequency of floating of $1.2 \mathrm{~Hz}$ during the period of silicon oxidation (versus $1.0 \mathrm{~Hz}$ at the positive polarity) and of $1.7 \mathrm{~Hz}$ in the intensive carbon oxidation period (versus $1.3 \mathrm{~Hz}$ at the positive polarity).

Thus, the article presents the results of high temperature modelling of converter process with the four gas blowing options: top, bottom, and two combined ones. It has been established that during the blowing, the low voltage potential application increases the brightness and temperature of the sub-lance area. The highest temperature corresponds to the combined blowing option, while the lowest one is reported for the bottom blowing. It has been noted that the low voltage potential application of positive polarity leads to an increase in the melt temperature accompanied by an increase in the brightness of the reaction zones.

The influence of the blowing type and polarity of the low voltage application on the gas jet penetration and the visual character of the reaction $\mathrm{zO}^{-}$ nes formation have been established. The greatest depth of jet penetration has been observed in the case of the top blowing. In the conditions of the combined blowing, the total volume of the reaction zones is higher, but the upper reaction zone gets smaller because of the influence of counter streams.

It has been noted that, during the silicon oxidation period, the diameter of the reaction zone is smaller; at the same time, it should be noted that the reaction zone is longer at the positive polarity; in the intensive carbon oxidation period, the longer reaction zone is reported for the negative polarity of the potential.

It has been assumed that in the sub-lance area, as a result of the influence of the electric field on the oxygen ions formed during thermal ionization in the high temperature zone during the blowing periods, as well as depending on the combination of the direction of oxygen flow and electric field forces, the gas flow additionally accelerates or slow down by $10-12 \%$, which causes a change in the parameters of the reaction zone in the sublance area. This effect can be used as an additional control effect on the melt during the converter blowing.

It has been established that the intensity and the frequency of $\mathrm{CO}$ babbles formation are influenced by: 1) the depth of their formation: the deeper the place of the formation of bubbles, the more complicated the formation process, 2) the priority of silicon or carbon oxidation: in the intensive carbon oxidation period, the intensity of formation and the frequency of bubble floating are higher than in the silicon oxidation period; and 3 ) the polarity of the potential: at the negative polarity of the potential, the frequency of $\mathrm{CO}$ bubbles formation is higher.

Acknowledgments. The authors appreciate valuable contribution of Prof. A. G. Cherniatevych, V. V. Vakulchuk, and E. V. Semykina (ISI NASU) to the laboratory experiments.

The authors declare that they have no conflict of interest. 


\section{REFERENCES}

1. Toshihiko Emi. (2015). Steelmaking Technology for the Last 100 Years: Toward Highly Efficient Mass Production Systems for High Quality Steels. ISIJ Int., 55(1), 36-66.

2. Smil, V. (2006). Transforming the Twentieth Century. Technical Innovations and Their Consequences. Oxford University Press.

3. Semykin, S. I., Polyakov, V. F. (2014). Application of low voltages in the converter smelting of steel. Steel in Translation, 44(9), 660-664.

4. Barker, K. J., Pauls, J. R., Rymarchyk, N., Jancosko, R. M. (1998). The making, shaping and treating of steel. $11^{\text {th }}$ ed. Oxygen steelmaking furnace. Ch. 8. AISE Steel Foundation, Pittsburgh, PA, 433.

5. Yavoyskiy, V. I., Yavoyskiy, A. V. (1987) Scientific foundations of modern steel production processes. Moscow: Metallurgija [in Russian].

6. Ohotskiy, V. B., Baptizmanskiy, V. I., Prosvirin, K. S., Shchedrin, G. A. (1973). The structure of the reaction zone when blowing metal with oxygen, Izvestiya. Ferrous metallurgy, 8, 50-53 [in Russian].

7. Cherniatevich, A. G., Zarvin, E. Ya. (1978). On the issue of high temperature modeling of the oxygen-converter process. Izvestiya. Ferrous metallurgy, 4, 40-46 [in Russian].

8. Cherniatevich, A. G. (1991). High temperature modeling of the oxygen-converter process. Izvestiya. Ferrous metallurgy, 12, 16-18 [in Russian].

9. Feiler, S. V., Protopopov, E. V., Chernyatevich, A. G. (2014). Combined injection of oxygen and neutral gas in the converter bath. Steel in Translation, 44(4), 258-263.

10. Semykin, S. I., Kiiashko, T. S., Semykina, E. V. (2011). Investigation of the peculiarities of the effect of low-voltage potential on the processes of metal refining in an oxygen converter. Metal and casting of Ukraine, 7, 29-34 [in Russian].

11. Stepanov, Ye. M., D’yachkov, B. G. (1968). Flame ionization in an electric field. Moscow: Metallurgy. 310 p. [in Russian].

Received 26.10.2020

Revised 03.02.2021

Accepted 29.03.2021

C.I. Семикін (https://orcid.org/0000-0002-7365-2259),

T.С. Голуб (https://orcid.org/0000-0001-9269-2953),

С.О. Дудченко (https://orcid.org/0000-0002-7319-9896)

Інститут чорної металургії ім. 3.І. Некрасова НАН України,

пл. акад. Стародубова, 1, Дніпро, 49107, Україна,

+380 56790 0512, office.isi@nas.gov.ua

ПРЯМЕ СПОСТЕРЕЖЕННЯ ВИСОКОТЕМПЕРАТУРНИХ

ОБЛАСТЕЙ МЕТАЛЕВОГО РОЗПЛАВУ

ПРИ КИСНЕВОМУ КОНВЕРТУВАННІ ІЗ ЗАСТОСУВАННЯМ

НИЗЬКОВОЛЬТНОГО ПОТЕНЦІАЛУ

Вступ. Процес кисневого конвертування, незважаючи на вже наявні вдосконалення, можна доповнити фізичними методами впливу, зокрема й нетрадиційним методом застосування низьковольтного потенціалу, розробленого в Інституті чорної металургії НАН України.

Проблематика. Дослідження способу застосування низьковольтного потенціалу на 60-, 160- та 250-тонних конвертерах показали, що технологія інтенсифікує теплофізичні та гідродинамічні процеси в системі газ-шлак-метал й підвищує ефективність конвертування.

Мета. Дослідження на високотемпературній фізичній моделі особливостей впливу на реакційні зони застосування низьковольтного потенціалу при різних варіантах продувки.

Матеріали й методи. Фізична моделі, що імітує верхню, нижню та комбіновану продувку киснем в умовах накладання низьковольтного потенціалу різної полярності до верхньої фурми. Для візуального спостереження та відео- 
реєстрації в одній зі стін зроблено вставку із прозорої кварцової пластини. Верхню продувку проводили через двосоплову фурму (діаметр сопел 1,7 мм з кутом нахилу до фурми $30^{\circ}$ ). Нижню продувку здійснювали через нижню фурму з діаметром центрального сопла 1,5 мм. Комбіновану продувку забезпечували поєднанням вказаних варіантів.

Результати. Візуальне спостереження за реакційними зонами за різних варіантів продувки показало, що найвища температура і найбільші розміри найяскравіших ділянок ванни відповідали комбінованому варіанту продувки, найнижча - донному варіанту продувки. При застосуванні низьковольтного потенціалу було встановлено, що під час періоду окислення кремнію реакційна зона була довшою при позитивній полярності на фурмі, а в період інтенсивного окислення вуглецю - при негативній полярності потенціалу.

Відео флотації бульбашок газу, ймовірно СО, показало, що вони утворюються більш інтенсивно у разі підведення негативної полярності до фурми.

Висновки. Застосована методика дозволила встановити особливості впливу полярності потенціалу, що підводиться до фурми, на геометричні параметри реакційної зони.

Ключові слова: кисневе конвертування, високотемпературне моделювання, реакційна зона, накладання низьковольтного потенціалу на фурму та металеву ванну під час продувки. 